\title{
Assessment of French patients with LPL deficiency for French Canadian mutations
}

Luc Foubert, Jean Luc De Gennes, Jean Pierre Lagarde, Ewa Ehrenborg, Alain Raisonnier, Jean Philippe Girardet, Michael R Hayden, Pascale Benlian

\begin{abstract}
Mutations in the LPL gene show high levels of allelic heterogeneity between and within different populations. Complete LPL deficiency has a very high prevalence in French Canadians, where only three missense mutations account for $>97 \%$ of cases, most consistent with founder mutations introduced early in Quebec by French immigrants. In order to determine whether these mutations were present in France, 12 unrelated French families with defined LPL deficiency were investigated for the presence of the mutations found in French Canadians. Of the 24 expected alleles, six $(25 \%)$ represented mutations in French Canadians (Gly188Glu four alleles, Asp250Asn and Pro207Leu one allele each). Comparison of French Canadian and French alleles identified the same haplotype in all carriers of the Gly188Glu and of the Asp250Asn, suggesting a common origin. In contrast, the Pro207Leu occurred on different haplotypes in France and Quebec, compatible with a different ancestral origin. $(\Im$ Med Genet 1997;34:672-675)
\end{abstract}

Biochemistry, Pitie

Salpétrière Hospital, Paris, France

L Foubert

J L De Gennes

J P Lagarde

A Raisonnier

Medical Genetics, University of British Columbia, Vancouver, Canada

E Ehrenborg

M R Hayden

$P$ Benlian

Paediatrics, Trousseau Hospital, Paris, France J P Girardet

Molecular Biology, Saint Antoine Hospital, Paris, France P Benlian

Correspondence to: Dr Benlian, Laboratoire de Biochimie, Biologie Cellulaire et Biologie Moléculaire, Hôpital Saint Antoine, 184 rue du Faubourg Saint Antoine, 75012 Paris, France.

Received 8 July 1996 Revised version accepted for publication 21 February 1997
Keywords: lipoprotein lipase; founder mutation; French Canadians

Lipoprotein lipase (LPL) is the rate limiting enzyme for the hydrolysis of triacylglycerols of plasma very low density lipoproteins and chylomicrons. ${ }^{1}$ Defective lipolysis in plasma results in familial chylomicronaemia, a recessive disorder usually manifesting early in life. ${ }^{2}$ Following the cloning of the LPL gene, ${ }^{3}$ more than 60 mutations have been identified as a cause for this disorder in Asians, blacks, and whites. ${ }^{45}$ Allelic heterogeneity for LPL mutations underlies most cases of LPL deficiency, with most patients being compound heterozygotes usually for two missense mutations. In addition, recurrent mutations that result in the same nucleotide or codon substitution have been observed in patients of different ancestries. $^{67}$

LPL deficiency has a general prevalence of $1 / 500$ in many populations. ${ }^{2}$ In contrast, the carrier frequency is increased to $1 / 40$ in French Canadians of the Saguenay-Lac Saint Jean region in the province of Quebec in Canada. ${ }^{8} 9$ Moreover, only three mutations (Gly188Glu and Pro207Leu in exon 5 and Asp250Asn in exon 6) account for more than $97 \%$ of cases in French Canadians with LPL deficiency. ${ }^{1011}$
The high disease prevalence, its relative genetic homogeneity, and the fact that distinct haplotypes segregate with each of these mutations, have been postulated as evidence for a founder effect for these mutations in French Canadians. ${ }^{12}$

If these are founder mutations introduced by French settlers, then these mutations should be present in France. Here, we have investigated the presence of LPL mutations observed in French Canadians in 12 unrelated families of French ancestry with defined LPL deficiency. All three mutations were found in five families. The Asp250Asn and the Gly188Glu were associated with the French Canadian haplotype in one and four subjects respectively, whereas the one carrier of the Pro207Leu had a different haplotype suggesting a distinct genetic origin.

\section{Subjects and methods}

FAMILIES OF FRENCH ANCESTRY WITH LPL DEFICIENCY

A total of 12 unrelated French families were ascertained through probands with LPL deficiency. All families had lived in France for at least three generations. A record was taken of the region of origin of members of the oldest generations. LPL deficiency was defined in probands as follows: (1) fasting chylomicronaemia ${ }^{2}$; (2) recurrent episodes of abdominal pain, lipaemia retinalis, eruptive xanthomata, hepatosplenomegaly, and acute pancreatitis; and (3) a plasma LPL activity below $10 \%$ of normal ${ }^{13}$ and a lowered LPL dimeric mass. ${ }^{14}$ Members of the families have given informed consent for these studies which were approved by the board of ethics at Pitié Salpétrière Hospital, Paris.

\section{DNA ANALYSIS}

Genomic DNA was extracted from blood leucocytes by a phenol chloroform method. In all probands, individual exons of the LPL gene were amplified by PCR as previously described. ${ }^{15}$ French Canadian mutations were detected in probands and their relatives by enzymatic restriction of PCR products. The Gly188Glu mutation was detected by AvaII restriction of exon 5. The Pro207Leu was detected by $D d e I$ restriction of a mismatch PCR product of exon 5. ${ }^{16}$ The Asp250Asn was detected by TaqI enzymatic restriction of exon 6. An SSCP analysis of the nine exons coding for LPL was performed in all probands. ${ }^{17}$ When a gene variant was detected, the mutation was identified by DNA sequencing. ${ }^{15}$ 
Table 1 Mutations observed in unrelated French patients with LPL deficiency

\begin{tabular}{|c|c|c|c|c|}
\hline Mutation & Amino acid change & $D N A$ change & Location & Reference \\
\hline Frameshift Glu35 & $\rightarrow$ Stop62 * & Ins $A^{183}$ & Exon 2 & 21 \\
\hline Frameshift Val69 & $\rightarrow$ Stop1 19 & $\Delta^{286} \mathrm{GT}^{287}$ & Exon 3 & 22 \\
\hline Frameshift Ala70 & $\rightarrow$ Stop1 19 & $\Delta{ }^{290}$ CCGC & Exon 3 & 23 \\
\hline Missense & Thr101 $\rightarrow$ Ala & $\mathrm{ACC} \rightarrow \mathrm{GCC}$ & Exon 3 & 23 \\
\hline Frameshift Asn120 & $\rightarrow$ Stop142 & $\Delta^{614} \mathrm{ACTA}^{617}$ & Exon 4 & 22 \\
\hline Missense & Asp156 $\rightarrow$ His * & $\mathrm{GAT} \rightarrow \mathrm{CAT}$ & Exon 5 & $t$ \\
\hline Missense & Gly $188 \rightarrow$ Glu * & $\mathrm{GGG} \rightarrow \mathrm{GAG}$ & Exon 5 & $23+$ \\
\hline Missense & Gly188 $\rightarrow$ Arg * & GGG $\rightarrow$ AGG & Exon 5 & 23 \\
\hline Missense & Pro $207 \rightarrow$ Leu & $\mathrm{CCG} \rightarrow \mathrm{CTG}$ & Exon 5 & $t$ \\
\hline Missense & Arg243 $\rightarrow$ Cys & $\mathrm{CGC} \rightarrow \mathrm{TGC}$ & Exon 6 & 7 \\
\hline Missense & Asp250 $\rightarrow$ Asn & $\mathrm{GAC} \rightarrow \mathrm{AAC}$ & Exon 6 & $23+$ \\
\hline Duplication & - & $2 \mathrm{~kb}$ & Exon 6 & 24 \\
\hline Deletion & - * & $2.1 \mathrm{~kb}$ & Exon 9 & 25 \\
\hline
\end{tabular}

${ }^{\star}$ Mutations observed on more than one allele.

†This report.

Table 2 Haplotypes observed in French families and in French Canadians with French Canadian mutations. Alleles of RFLPs are numbered according to decreasing band size. Alleles of SSRs are designated according to the number of repeats. Alleles that do not match the French Canadian haplotype are underlined

\begin{tabular}{|c|c|c|c|c|c|c|}
\hline \multirow[b]{2}{*}{ Mutation } & \multirow[b]{2}{*}{ Subjects } & \multicolumn{5}{|c|}{ Polymorphic markers of the LPL gene } \\
\hline & & $S^{\prime}(G T) n$ & PvuII & $(T T T A) n$ & HindIII & MnlI \\
\hline \multirow{5}{*}{$\begin{array}{l}\text { Gly188 } \rightarrow \text { Glu } \\
\quad(\text { GGG } \rightarrow \text { GAG })\end{array}$} & French Canadians & 16 & 1 & 10 & 2 & 1 \\
\hline & French family 1 & 16 & 1 & 10 & 2 & 1 \\
\hline & French family 2 & 16 & 1 & 10 & 2 & 1 \\
\hline & French family 3 & 16 & 1 & 10 & 2 & 1 \\
\hline & French family 4 & 16 & 1 & 10 & 2 & 1 \\
\hline \multirow{2}{*}{$\begin{array}{l}\text { Asp250 } \rightarrow \text { Asn } \\
\quad(\text { GAC } \rightarrow \text { AAC })\end{array}$} & French Canadians & 16 & 2 & 11 & 2 & 1 \\
\hline & French subject & 16 & 2 & 11 & 2 & 1 \\
\hline \multirow{2}{*}{$\begin{array}{l}\text { Pro207 } \rightarrow \text { Leu } \\
\quad(\text { CCG } \rightarrow \text { CTG })\end{array}$} & French Canadians & 16 & 2 & 11 & 2 & 1 \\
\hline & French family 1 & $\underline{\underline{20}}$ & 2 & $\underline{\underline{10}}$ & 2 & $\stackrel{2}{=}$ \\
\hline
\end{tabular}

A total of five LPL gene polymorphisms were used for haplotyping in French families and in two French Canadians identified as heterozygous or homozygous for either of the three founder mutations. The 5'GT microsatellite upstream of the LPL gene and the VNTR in intron 6 were detected after radiolabelling of PCR products. ${ }^{12}{ }^{18}$ Intragenic RFLPs (PouII in intron 6 , HindIII in intron $8, M n l \mathrm{I}$ in exon 9)

Family 1

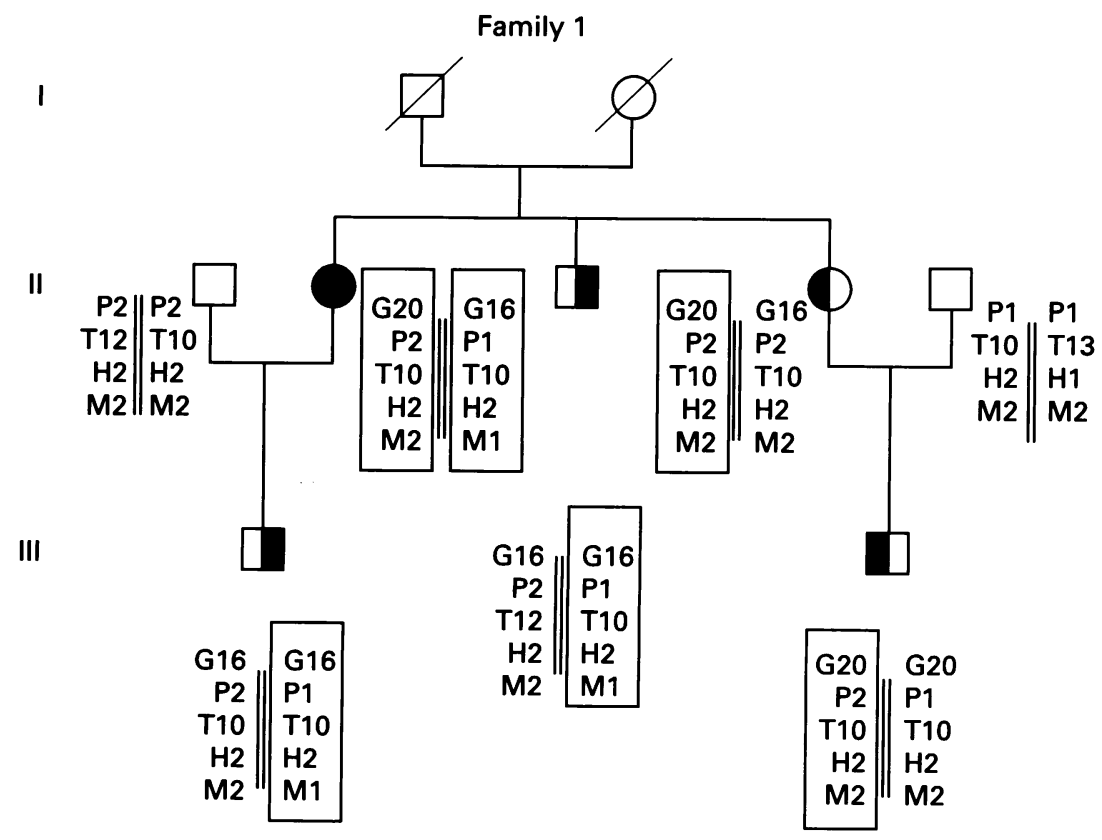

were detected after enzymatic cleavage of PCR products. ${ }^{19} 20$

\section{Results}

Of the 24 expected mutant alleles, six (25\%) were identified as the mutations found in French Canadians by enzymatic restriction and DNA sequencing. The Gly 188 Glu mutation in exon 5 was found in four unrelated probands who were compound heterozygotes. One of these probands also carried the Pro207Leu mutation in exon 5. One proband with no living relatives was heterozygous for the Asp250Asn mutation in exon 6. In addition to these three mutations, other mutations were identified in the LPL gene accounting for all expected mutant alleles in probands with LPL deficiency (table 1).

DNA haplotypes were constructed in families (fig 1) using three RFLPs and two short sequence repeats (SSRs). The same markers were simultaneously analysed in pairs of unrelated French Canadians (table 2). Of the 560 theoretically possible haplotypes, only the French Canadian haplotype was found in all of the four carriers of the Gly188Glu mutation. The carrier of the Asp250Asn was homozygous for the haplotype observed in French Canadians. Surprisingly, the haplotype associated with the Pro207Leu mutation differed from the French Canadian haplotype for the two SSRs and for the MnlI RFLP, suggesting in this case a distinct genetic origin. Families with the Gly188Glu and the Pro207Leu mutation originated from Paris, Champagne, Burgundy, and Lyon. The patient with the Asp250Asn mutation originated from Provence.

\section{Discussion}

A founder effect for three point mutations has been suggested as a cause for allelic homogeneity of LPL deficiency in French Canadians. Pro207Leu accounts for about $73 \%$ of muta-

Family 2

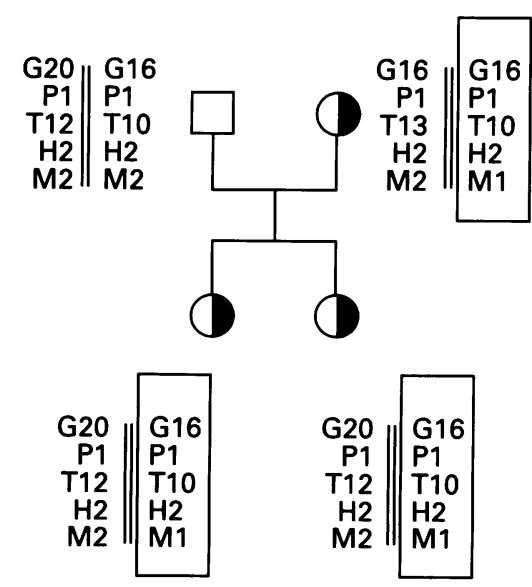

Pro207Leu

Gly188Glu

Figure 1 Haplotypes of the LPL gene segregating with mutations Gly188Glu and Pro207Leu in families 1 and $2 . G=5^{\prime}(G T)_{n}, P=P v u I I, T=(T T T A)_{,}$, $H=H i n d I I, M=M n l I$. Alleles of RFLPs are numbered according to decreasing band size. Alleles of short sequence repeats (SSRs) are numbered according to the number of repeats. Haplotypes segregating with a mutation are boxed. 
tions, Gly $188 \mathrm{Glu}$ for $24 \%$, while the Asp250Asn mutation is infrequent (2\%) Genealogical studies have suggested that French Canadians comprise two major subgroups: the first group from the Perche region in France, which established in the SaguenayLac Saint Jean region in eastern Quebec during the late 17th century, where the Pro207Leu mutation is most prevalent, ${ }^{26}$ and a second group which emigrated more recently, mainly from the western part of France and settled along the Saint Lawrence river in western Quebec, where the Gly188Glu mutation is most frequent. ${ }^{27}$ In contrast, allelic heterogeneity characterises LPL deficiency in France, with mutations found in French Canadians representing only $1 / 4$ of the mutations.

Remarkably, the Gly188Glu mutation was relatively common, accounting for $16.7 \%$ of French cases, in a proportion similar to French Canadians with LPL deficiency. The Gly $188 \mathrm{Glu}$ mutation was associated with the same chromosome haplotype as the French Canadian mutation. This haplotype is not, however, specific to French Canadians with this mutation, also being reported in other populations of European origin, such as Austria, ${ }^{28}$ Denmark, Great Britain, ${ }^{15}$ Germany, ${ }^{29}$ Holland, ${ }^{30}$ Poland, ${ }^{15}$ Spain, ${ }^{31}$ and the USA. ${ }^{32}$ Moreover, patients from India or Malaysia emigrating to South Africa are also carriers of this mutation. ${ }^{34}$ Thus, the Gly $188 \mathrm{Glu}$ mutation represents a cause of LPL deficiency, apparently as common in France as in other countries. Therefore, this suggests that French Canadian founders who established in the western part of Quebec were carriers of a mutation that was quite common and perhaps widespread in France before they had emigrated to Canada.

In contrast to the Gly188Glu (GGG $\rightarrow$ GAG) mutation, the French Canadian Pro207Leu (CCG $\rightarrow$ CTG) and Asp250Asn (GAC $\rightarrow$ AAC) mutations involve a $\mathrm{CpG}$ dinucleotide, a type of mutation giving rise to recurrent mutations in different genetic backgrounds. ${ }^{35}$ Here, the Asp250Asn mutation found in France shared a common chromosomal haplotype with French Canadians and with a Dutch patient who was also a carrier of this mutation, "1 suggesting a common origin. Although no mention was made about the associated haplotype, this mutation has also been described in subjects originating from Italy and France, ${ }^{36}$ suggesting that this mutation may also be relatively common in Europe. Here, the patient originated from Provence, a region known to have historical and geographical relationships with Italy. Therefore, the data are at present insufficient to determine conclusively from which part of Europe the actual Canadian founders for the Asp250Asn mutation originate.

An unexpected finding of this study was that the most frequent Pro207Leu mutation in French Canadians was found in France but on a different chromosomal haplotype. Several hypotheses may be proposed to account for these findings. First, neutral polymorphisms, especially SSRs used above for haplotyping, have a higher rate of mutagenesis than functional mutations resulting from nucleotide substitutions. ${ }^{37}$ However, although allelic differences could result from a variation at one locus through this mechanism, it is very unlikely that they result from independent mutagenic events at three different loci while the Pro207Leu mutation remains stable.

The second hypothesis would be that the French Canadian Pro207Leu mutation may have originated from a very specific group in France, which we have not detected. Similarly to LPL deficiency, a mutation (Met1 Val) of the phenylalanine hydroxylase gene is highly prevalent in French Canadians of the Saguenay-Lac Saint Jean region in Quebec, and is associated with a unique haplotype (haplotype 1). French founders with phenylketonuria have been identified in the region of Mortagne au Perche in France. ${ }^{38}$ Indeed, none of the 12 families analysed here originated from Perche. Therefore, screening for this mutation in patients with LPL deficiency from Perche could still identify this particular mutation.

Finally, the Pro207Leu mutation has also been reported in a German patient ${ }^{7}$ and in a patient studied in the USA for whom the ethnic origin was not specified. ${ }^{33}{ }^{39}$ Interestingly, the haplotype found in the German patient matched the French Canadian haplotype for the four markers analysed (PvuII, VNTR intron 6, HindIII, BamHI). ${ }^{71}$ Another unexpected genetic origin has been observed in French Canadians with phenylketonuria. ${ }^{40}$ Founders with the Arg408Trp mutation in the phenylalanine hydroxylase gene and haplotype 2 had a Celtic origin, their contemporary descendants at present residing in Ireland and western Scotland. Therefore, another intriguing possibility is that the Pro207Leu mutation, which is highly prevalent in French Canadians of the eastern region of Quebec, may in fact have another origin through early admixture with another population.

In conclusion, the three mutations found to cause LPL deficiency in French Canadians were identified in French patients with LPL deficiency. The Gly188Glu and Asp250Asn mutations occur on common chromosomal haplotypes seen in France and in other parts of Europe. However, the French Canadian Pro207Leu was not identified, suggesting that this mutation may be localised to a very specific region in France, presumably the Perche region, an area from which many French Canadians originated. Alternately, this mutation may also originate from another population through early admixture with French Canadian settlers.

This work was supported by grants from INSERM 91CN45 and from the Comité Français de Coordination des Recherches sur l'Atherosclerose et le Cholesterol (ARCOL) to PB and from grants from MRC Canada to MRH. LF was recipient of a grant from ARCOL. PB was recipient of a research grant from the Fondation pour la Recherche Médicale and of a fellowship from the International Atherosclerosis Society. EE was recipient of grant from the Eric and Edith Fernström Foundation.

1 Olivecrona T, Bengstsson-Olivecrona G. Lipoprotein lipase and hepatic lipase. Curr Opin Lipidol 1993;4:187-96.

and hepatic lase Cur Brunzell J. Familial lipoprotein lipase deficiency and other 
Beaudet AL, Sly WS, Valle D. The metabolic basis of inherited disease. 7th ed. Highstown, New Jersey: McGraw Hill, 1995:1913-32.

3 Wion K, Kirchgessner T, Lusis AJ, Schotz MC, Lawn RM. Human lipoprotein lipase complementary DNA sequence. Science 1987;235:1638-41.

4 Hayden MR, Ma Y, Brunzell J, Henderson HE. Genetic variants affecting human lipoprotein and hepatic lipases. Curr Opin Lipidol 1991;2:104-9.

5 Benlian P. La lipoprotéine lipase, enzyme du remodelage des lipoprotéines riches en triglycérides. In: Génétique et dyslipidémies. Paris: Editions INSERM, 1996:79-89.

6 Henderson HE, Ma Y, Hassan MF, et al. Amino acid substitution (Ile ${ }^{194} \mathrm{Thr}$ ) in exon 5 of the lipoprotein lipase gene causes lipoprotein lipase deficiency in three unrelated probands. Support for multicentric origin. $f$ Clin Invest 1991;87:2005-11.

$7 \mathrm{Ma}$ Y, Liu MS, Chitayat D, et al. Recurrent missense mutations at the first and second base of codon $A^{2} G^{24}$ in human lipoprotein lipase causing chylomicronemia in patients of different ancestries. Hum Mutat 1994;3:52-8.

8 Gagné C, Brun LD, Julien P, Moorjani S, Lupien PJ. Primary lipoprotein lipase activity deficiency: clinical investigation of a French Canadian population. Can Med Assoc $\mathcal{f} 1989 ; 140: 405-11$.

9 Dionne C, Gagné C, Julien P, et al. Genetic epidemiology of lipoprotein lipase deficiency in Saguenay-Lac-St-Jean (Quebec, Canada). Ann Genet (Paris) 1992;35:89-92.

$10 \mathrm{Ma} \mathrm{Y}$, Henderson HE, Murthy MRV, et al. A mutation in the lipoprotein lipase gene as the most common cause of familial chylomicronemia in French Canadians. $N$ Engl $\mathcal{F}$ Med 1991;324:1761-6.

$11 \mathrm{Ma} Y$, Wilson BI, Bijvoet $S$, et al. A missense mutation (Asp ${ }^{250} \mathrm{Asn}$ ) in exon 6 of the human lipoprotein lipase gene causes chylomicronemia in patients of different ancestries. Genomics 1992;13:649-53.

12 Wood S, Schertzer M, Hayden M, Ma Y. Support for a founder effect for two lipoprotein lipase (LPL) gene mutations in French Canadians by analysis of GT microsateltions in French Canadians by analysis of GT microsate-
lites flanking the LPL gene. Hum Genet 1993;91:312-16.

13 Babirak S, Iverius PH, Fujimoto WY, Brunzell JD. Detection and characterization of the heterozygote state for Detection and characterization of the heterozygote state for
lipoprotein lipase deficiency. Arteriosclerosis 1989;9:326-34

14 Iverius PH, Brunzell JD. Human adipose lipoprotein lipase: changes with feeding and relationship to postheparin changes with feeding and relationship to pos
plasma enzyme. Am F Physiol 1985;249:E107-14.

15 Monsalve MV, Henderson $H$, Roederer G, et al. A missense mutation at codon 188 of the human lipoprotein lipase gene is a frequent cause of lipoprotein lipase deficiency in persons of different ancestries. $\mathcal{F}$ Clin Invest 1990;86:72834.

16 Bijvoet SM, Hayden MR. Mismatch PCR: a rapid method to screen for the Pro207Leu mutation in the lipoprotein lipase (LPL) gene. Hum Mol Genet 1992;1:541.

17 Gagné E, Genest J Jr, Zhang H, Clarke LA, Hayden MR. Analysis of DNA changes in the LPL gene in patients with familial combined hyperlipidemia Arterioscler Thromb 1994;14:1250-7.

18 Zuliani G, Hobbs HH. Tetranucleotide repeat polymorphism in the LPL gene. Nucleic Acids Res 1990;18:4958.

19 Gotoda T, Yamada N, Murase T, et al. Detection of three separate DNA polymorphisms in the human lipoprotein lipase gene by gene amplification and restriction endonulipase gene by gene amplification and
clease. $¥$ Lipid Res 1992;33:1067-72.

20 Hata A, Robertson M, Emi M, Lalouel JM. Direct detection and automated sequencing of alleles after electrophoretic strand separation: identification of a common nonsense mutation in exon 9 of the human lipoprotein lipase gene. Nucleic Acids Res 1990;18:5407-11.

21 Benlian P, Foubert L, Gagné E, et al. Complete paternal isodisomy for chromosome 8 unmasked by lipoprotein lipase deficiency. Am $\mathcal{f}$ Hum Genet 1996;59:431-6.
22 Foubert L, De Gennes JL, Benlian P, Truffert J, Miao L, Hayden MR. Compound heterozygosity for frameshift mutations in the gene for lipoprotein lipase in a patient with mutations in the gene for lipoprotein lipase in a patien

23 Benlian P, De Gennes JL, Foubert L, Zhang H, Gagné E, Hayden MR. Premature atherosclerosis in patients with familial chylomicronemia caused by mutations in the lipoprotein lipase gene. $N$ Engl f Med 1996;335:848-54.

24 Devlin RH, Deeb S, Brunzell J, Hayden MR. Partial gene duplication involving exon- $A l u$ interchange results in lipoprotein lipase deficiency. Am $\mathcal{F}$ Hum Genet 1990;46:112-19.

25 Benlian P, Etienne J, De Gennes JL, et al. A homozygous gene deletion of exon 9 causes lipoprotein lipase deficiency: possible intron-Alu recombination. $\mathcal{F}$ Lipid Res 1995;36: 356-66.

26 Normand T, Bergeron J, Fernandez-Margallo T, et al. Geographic distribution and genealogy of mutation 207 of the lipoprotein lipase gene in the French Canadian population of Quebec. Hum Genet 1992;89:671-5.

27 Bergeron J, Normand T, Bharucha A, et al. Prevalence, geographical distribution and genealogical investigations of mutation 188 of lipoprotein lipase gene in the French Canadian population of Quebec. Clin Genet 1992;41:20610.

28 Paulweber B, Wiebusch H, Miesenboeck G, et al. Molecular basis of lipoprotein lipase deficiency in two Austrian families with type I hyperlipoproteinemia. Atherosclerosis 1991; lies with type
$86: 239-50$.

29 Funke H, Wiebusch H, Paulweber B, Assmann G. Identification of the molecular defect in a patient with type I hyperlipidemia. Arteriosclerosis 1990;10:830.

30 Bruin T, Tuzgöl S, Mulder WJ, et al. A compound heterozygote for lipoprotein lipase deficiency, $\mathrm{Val}^{69} \mathrm{Leu}$ and Gly ${ }^{188} \mathrm{Glu}$ : correlation between in vitro LPL activity and clinical expression. 7 Lipid Res 1994;35:438-45.

31 Reina M, Brunzell JD, Deeb SS. Molecular basis of familial chylomicronemia: mutations in the lipoprotein lipase and apolipoprotein C-II genes. $₹$ Lipid Res 1992;33:1823-32.

$32 \mathrm{Emi} \mathrm{M}$, Wilson DE, Iverius $\mathrm{PH}$, et al. Missense mutation (GlyGlu $^{188}$ ) of human lipoprotein lipase imparting functional deficiency. $\mathcal{F}$ Biol Chem 1990;265:5910-16.

33 Sprecher DL, Kobayashi J, Rimaszewski M, et al. A Trp ${ }^{64}$ nonsense mutation in the lipoprotein lipase gene. $\mathcal{F}$ Lipid Res 1992;33:859-66.

34 Henderson HE, Hassan MF, Berger GMB, Hayden MR. The lipoprotein lipase Gly ${ }^{188}$ Glu mutation in South Africans of Indian descent: evidence suggesting common origins and an increased frequency. $\mathcal{F}$ Med Genet 1993;29: 119-22.

35 Cooper DN, Youssoufian H. The CpG dinucleotide and human genetic disease. Hum Genet 1988;78:151-5.

36 Ishimura-Oka K, Semenkovich CF, Faustinella F, et al. A missense mutation (Asp ${ }^{250} \mathrm{Asn}$ ) in the lipoprotein lipase gene in two unrelated families with familial lipoprotein lipase deficiency. $\mathcal{F}$ Lipid Res 1992;33:745-54.

37 Jeffreys AJ, Royle NJ, Wilson V, Wong Z. Spontaneous mutation rates to new length alleles at tandem repetitive hypervariable loci in human DNA. Nature 1988;332:27881 .

38 Lyonnet S, Melle D, De Braekeleer M, et al. Time and space clusters of the French-Canadian M1V phenylketonuria mutation in France. Am $\mathcal{F}$ Hum Genet 1992;51:191-6.

39 Sprecher DL, Knauer SL, Black DM, et al. Chylomicronretinyl palmitate clearance in type I hyperlipidemic

40 Scriver CR, Kaufman S, Eisensmith RC, Woo SLC. The hyperphenylalaninemias. In: Scriver CR, Beaudet AL, Sly WS, Valle D. The metabolic basis of inherited disease. 7th ed. Chap 27. Highstown, New Jersey: McGraw Hill, 1995: 1015-75. 